\title{
Protection and Purity: Symbolic Functions of the Iron Age Saunas of the Iberian Northwest
}

\author{
Nadya H. Prociuk
}

\begin{abstract}
Iron Age saunas, unique to the Castro Culture of northwestern Iberia, have puzzled archaeologists since the nineteenth century. Initially interpreted as kilns, crematoriums, or ovens, their function has since been established as bathing structures; however, the social significance of these saunas has yet to be firmly established. This study provides a new approach to understanding the ways in which Castro communities utilized specialized buildings to serve specific needs related to ritual cleansing and protection. Through an analysis of their placement, structure and decoration, I argue that these buildings functioned to purify and protect people of Castro communities from spiritual and physical danger. Members of Castro society inhabited a world buffeted by the shifting political and economic powers of the Iron Age. The bath structures under study, covered in apotropaic symbols, functioned in liminal spaces to cleanse and prepare Castro people for the dangers that awaited them beyond the walls of their communities and neutralized any potential spiritual contamination they may have acquired upon their return.
\end{abstract}

\begin{abstract}
Now some of the peoples that dwell next to the Durius River live, it is said, after the manner of the Laconians-using anointing-rooms twice a day and taking baths in vapours that rise from heated stones, bathing in cold water, and eating only one meal a day; and that in a cleanly and simple way. (Strabo 1903, 3.3.6)
\end{abstract}

\section{Introduction}

The European Iron Age (approximately 1100 BC-AD 100) was a cauldron for complex cultural interaction and change. The collapse of the Bronze Age trade networks and social systems left gaps providing room for new powers and ways of life to emerge. Ultimately Rome and Carthage, rising titans of the Mediterranean world, became pitted against each other in bids for economic and political dominance of the Mediterranean. Far from the wine-dark sea, the societies of western Europe created their own networks of alliance and trade, operating according to codes of conduct different enough from those of the Mediter- ranean to be considered not only foreign, but barbarous. The people of whom Strabo wrote in the opening epigraph, who dwelt next to the Durius [Douro] River, were perched on the edge of their known world, facing down the wild expanse of the Atlantic to the west and the slowly creeping reach of the Roman Empire to the south and east. Identified today as the Castro Culture (Silva 2007a), the people of the northwest of the Iberian peninsula inhabited a world in which their survival depended on forming connections with other groups through trade, knowledge exchange and alliances. However, that very survival was threatened by larger powers that would, ultimately, overtake the entire Iberian peninsula and alter the identities of its inhabitants forever.

In the time before and during the Roman conquest, the people of the Castro Culture, in an effort to cultivate stability in uncertain times, developed social strategies to combat the threats they were exposed to from the larger world. One such strategy is represented in the construction and use of ritual baths unique to the Castro area. These baths, recognized 
as a hallmark of the Castro Culture (Armada Pita 2001; Calo Lourido 1994; García Quintela \& SantosEstévez 2015; Parcero Oubiña \& Cobas Fernández 2004; Queiroga \& Dinis 2008/2009; Ríos 2002; Silva $2007 a, b)$, have been the subject of long debates regarding their purpose. I argue that the Castro baths, based on their specialized structure, location and symbolic decoration, were used to safeguard the community from spiritual contamination. This was achieved through rituals of transition and purification. These rituals were meant to fortify those who ventured beyond their settlements in order to create ties with the outside world and, by cleansing, make them safe again upon their return. This use worked to address an issue that all societies inevitably face: the need to cope with social stressors and instability.

\section{Background}

The Castro Culture is an archaeologically defined group of settlements and material culture which has a marked presence in the northwest of the Iberian Peninsula from the end of the Bronze Age to the time of Roman occupation of the area, between 1000 вс and AD 175 (Silva 2007a). The material characteristics of the Castro Culture include fortified hilltop settlements known as castros, dark micaceous ceramics, life-sized warrior statues and the use of specialized sauna or bath structures, which are the subject of this analysis. As with many archaeologically defined cultures, the precise geographical, temporal and cultural boundaries of the Castro Culture continue to be debated, but for clarity in this paper I use the conventionally accepted definitions.

The geographical area of the Castro Culture is defined by the Atlantic Ocean to the north and west, the Vouga River in the south and the Chaves-Verin geological fault to the west (López Cuevillas 1933; Queiroga 2003; Silva 2007a) (Fig. 1). This area is characterized by a riverine landscape carved from granitic bedrock, pocketed with schist and quartzite, and laced with veins of tin, silver and gold (Lemos et al. 2011; Queiroga 2003). While the coastal landscape is flat, the majority of the Castro region is dominated by hills and valleys created by the many rivers of the area, some of which are auriferous (Silva 2007a). The highly acidic sediments and granitic substrate of the region prevent the preservation of organic materials, posing substantial difficulties of interpretation due to lack of direct evidence for perishable organic materials (Parcero Oubiña \& Cobas Fernández 2004).

Throughout the Iron Age, individual Castro settlements appear to have been relatively self-sufficient, relying on a subsistence economy combining agro- pastoralism and trade, and many communities also exploited maritime and riverine resources. There is also evidence that each castro collected and processed metallic ores for local use as well as for trade (Queiroga 2003).

The available archaeological and ethnohistorical evidence regarding the social structure of the Castro Culture points towards kin-based social units governed at each site by a council of elders, which grew increasingly stratified over the course of the Iron Age and into the Roman period. This stratification was marked by expanding incorporation of storage facilities for surplus agricultural produce within domestic compounds, the increased importation of foreign goods and the proliferation of elaborate personal adornment (Parcero Oubiña \& Cobas Fernández 2004; Queiroga 2003; Sastre 2011). Towards the end of the Iron Age and the beginning of the Roman period, communities also began to produce communal monumental features, such as warrior statues and the ritual baths of this study.

Initially perceived as a monolithic cultural entity spanning the entire northwest of the peninsula, more recent research on the Castro Culture has led to the recognition of regional variation and differences in material culture, most distinctly divided between the northern and southern areas of Castro settlement distribution (Queiroga 2003). Incidentally, the dividing line between northern and southern material forms is the Minho River, which has remained the border between Spain and Portugal since AD 1297.

This difference in material culture between the north and south includes the distribution of large granite warrior statues and ritual baths with elaborately carved pedras formosas, or 'beautiful stones', mainly in the southern region. There are currently 26 known and possible bath structures in the Castro area, distributed between the northern region (corresponding to the Roman administrative territory of the Conventus lucensis in the current Spanish autonomous community of Galicia) and the southern region (corresponding to the Conventus bracaraugustanus, now the northwest of Portugal) (AlmagroGorbea \& Álvarez-Sanchís 1993; García Quintela \& Santos-Estévez 2015). The northern baths were constructed above ground using the native schist of the area, and are composed of only two to three rooms, lacking the elaborate granite pedras formosas of the southern baths (García Quintela \& Santos-Estévez 2015; González-Ruibal 2004; Lorrio 2005). However, Alfredo González-Ruibal (2004, 131-2) suggests that the northern baths may in fact have had a variation of the pedras formosas, carved from wood instead of stone. The reasons for the structural differences 


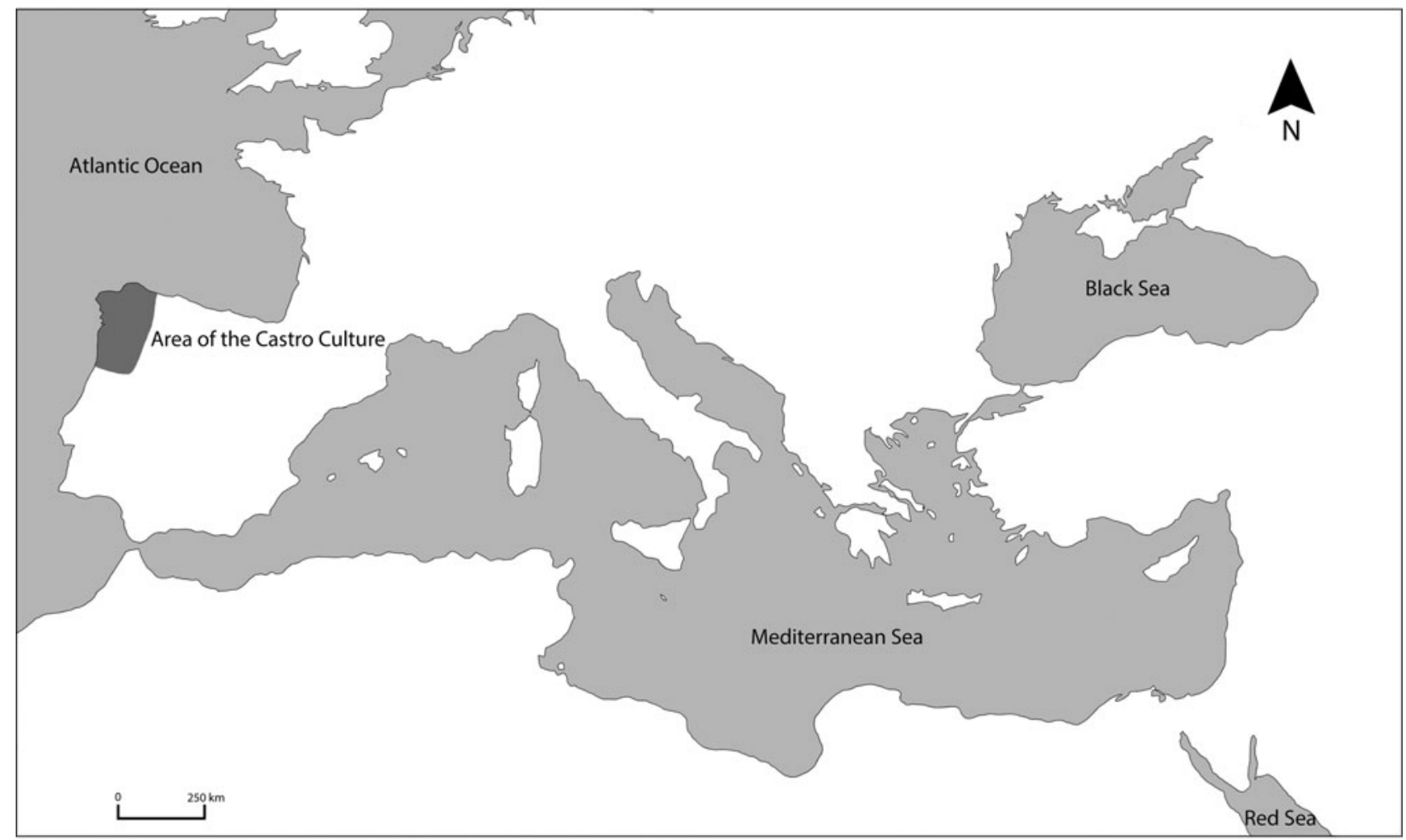

Figure 1. Map of Europe, the Mediterranean and North Africa showing the location of the Castro Culture in northwestern Iberia.

between the northern and southern baths are not entirely clear, though it is likely that local topography played an important role. The local schist of the northern region does not lend itself to forming the types of monumental slabs found throughout the architecture of the granitic southern region. Francisco Queiroga $(2003,25)$ also suggests that earlier bath structures may have been made partially or entirely of wood or other perishable materials, thus limiting their preservation. The southern baths, located between the Douro and Minho rivers in northern Portugal (Fig. 2), have been better preserved and more extensively studied than the northern baths, and will form the basis of the following analysis.

There is no agreement on the exact number of baths in the southern Douro-Minho region. The most recent estimate by Marco García Quintela and Manuel Santos-Estévez (2015) lists 15 bath locations, three of which they consider to be of a doubtful or incomplete nature, and one (Monte Padrão) which has not yet been published, which are listed in Table 1.

In addition to the difference in construction material and structural layout, the main contrast between the northern and southern baths is the presence of a pedra formosa or 'beautiful stone' at some of the
Table 1. List of sites associated with bath structures in the Douro-Minho region. *Sites considered doubtful or incomplete by García Quintela and Santos-Estévez (2015).

\begin{tabular}{|l|l|}
\hline Site & County \\
\hline Alto das Eiras & Vila Nova de Famalicão \\
\hline Alto das Quintas & Póvoa de Lanhoso \\
\hline Braga & Braga \\
\hline Citânia de Briteiros & Guimarães \\
\hline Castro de Eiras & Braga \\
\hline Castro de Roques & Viana do Castelo \\
\hline Castro de Monte Padrão & Santo Tirso \\
\hline Monte de Saia & Barcelos \\
\hline Ribalonga* & Alijó \\
\hline Castro de Sabroso* & Guimarães \\
\hline Citânia de Sanfins & Paços de Ferreira \\
\hline Santa Maria de Galegos & Barcelos \\
\hline $\begin{array}{l}\text { Sardoura (also known as Monte } \\
\text { Castro) }\end{array}$ & Castelo de Paiva \\
\hline $\begin{array}{l}\text { Tongobriga (also known as } \\
\text { Freixo) }\end{array}$ & Marco de Canaveses \\
\hline Vermoim* & Vila Nova de Famalicão \\
\hline
\end{tabular}




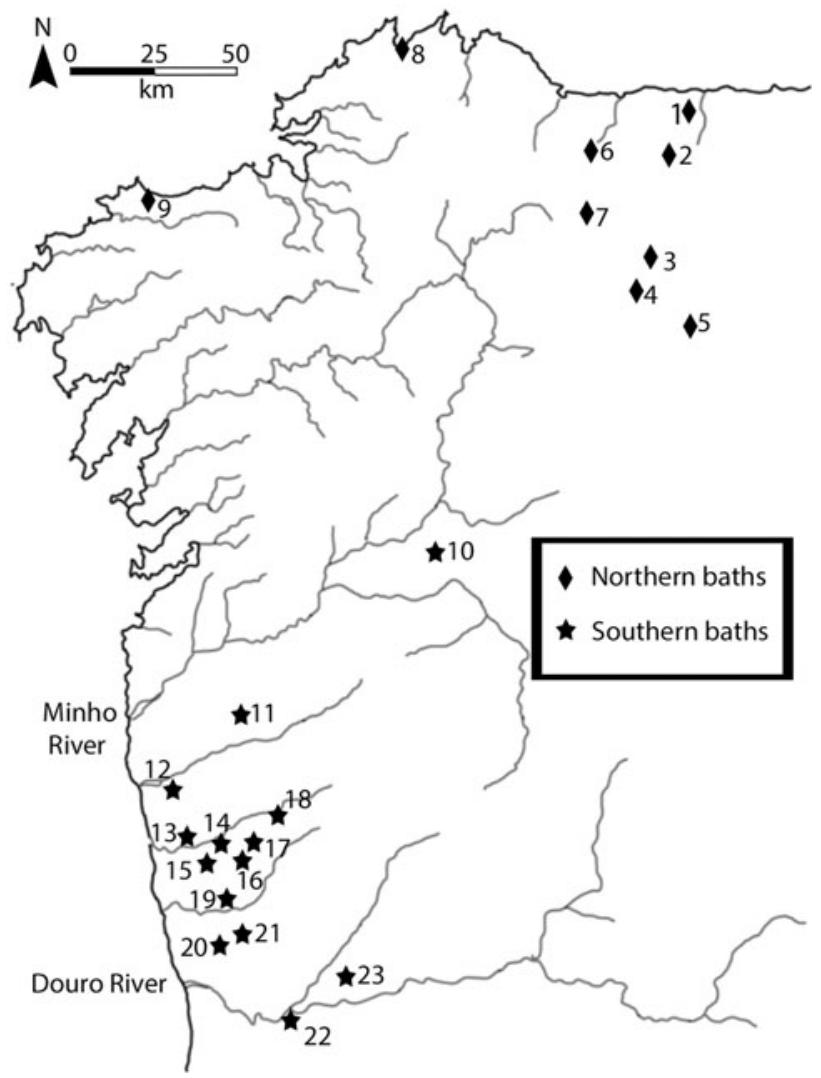

Figure 2. Locations of bath structures in northwestern Iberia (after García Quintela \& Santos-Estévez 2015):

(1) Coaña; (2) Pendia; (3) Chao Sanmartín; (4) Pelou;

(5) Cecos; (6) Taramundi; (7) Castelón de Castañoso;

(8) Punta dos Prados, (9) Borneiro; (10) Armea;

(11) Castro das Eiras; (12) Castro de Roques; (13) Santa Maria de Galegos; (14) Braga; (15) Monte da Saia;

(16) Castro de Sabroso; (17) Citânia de Briteiros; (18) Alto das Quintas; (19) Castro de Monte Padrão; (20) Citânia de Sanfins; (21) Sardoura; (22) Tongobriga.

southern baths (e.g. Figs. 3, 4 \& 5A). These massive polygonal granite slabs, sometimes simply decorated with a single motif, or exuberantly carved with multiple designs, are recognized as a defining characteristic of the Castro Culture, and are present at seven of the 15 sites in the southern region, five of them in situ. At least one site, Briteiros, has two pedras formosas associated with it (illustrated in Figs. 3 \& 4), though the original location of one stone is unknown.

Written sources of information about the Castro Culture come to us from Greek and Roman writers who chronicled the geography and history of the ancient world. Writers such as Strabo, Appian, Diodorus Siculus, Polybius, Silius Italicus, Pliny the Elder and Pomponius Mela all touched on the people of the northwest of Iberia in their writing, with varying degrees of precision and bias; however, it has been accepted that Strabo (1903) was referring to the inhabitants of the Castro region when he wrote of the people who 'dwell next to the Durius [Douro] River' (3.3.6). In the passage (quoted above), Strabo refers to the anointing rooms used twice a day by the people living near the Douro, and claims that they bathe in cold water and steam emitted from hot stones. No other direct reference to this practice has been found in the ancient sources, though some scholars (Armada Pita 2001; Pena Graña 1999) argue that an oblique reference is made to them by Diodorus Siculus (1961, 33.7.1-4) in his passage discussing the wedding of the Lusitanian rebel leader Viriatus, in which Viriatus refuses to wash or sit down to his own wedding feast. Modern scholars have taken Strabo's passage to support the hypothesis that the specialized structures found within the Castro region were used as saunas or bath houses (González-Ruibal 2004; Lemos et al. 2011; Silva 2007a).

\section{Archaeological perspectives on the Castro baths}

Since the archaeological discovery of the first such specialized structure by Martins Sarmento in the late nineteenth century and the subsequent excavation and typological definition of other similar structures over the course of the twentieth, there have been several competing hypotheses regarding the nature and use of these buildings. Initially Sarmento believed that the structures were used as sanctuaries or shrines (Silva 2007a). Others have argued that they were used as ovens, either for baking bread (Gómez Tabanera 1980) or firing ceramics (Fernández Fuster 1953), or were used as foundries (Monteagudo 1952), abattoirs (Azevedo 1946), or crematoriums (Romero Masiá 1976). However, in 1955 Conde Valvís (1955) suggested that these unique structures may have been used as baths, echoed in part by Chamoso Lamas (1955), and later advocated by Ferreira Almeida (1974) based on excavations from Sanfins, as well as by Armando Coelho Ferreira da Silva (1983/1984; 2007a) from excavations at Santa Maria de Galegos. As more structures have been excavated, the lack of evidence for activities such as ceramic production, animal slaughter, or human cremation, in addition to the accumulation of the evidence discussed below, has led to the acceptance of the theory that these structures were used as saunas or baths in the way described by Strabo two millennia ago.

Alhough it has now been accepted that these structures functioned as saunas or baths, debate has continued about whether they were the result of 


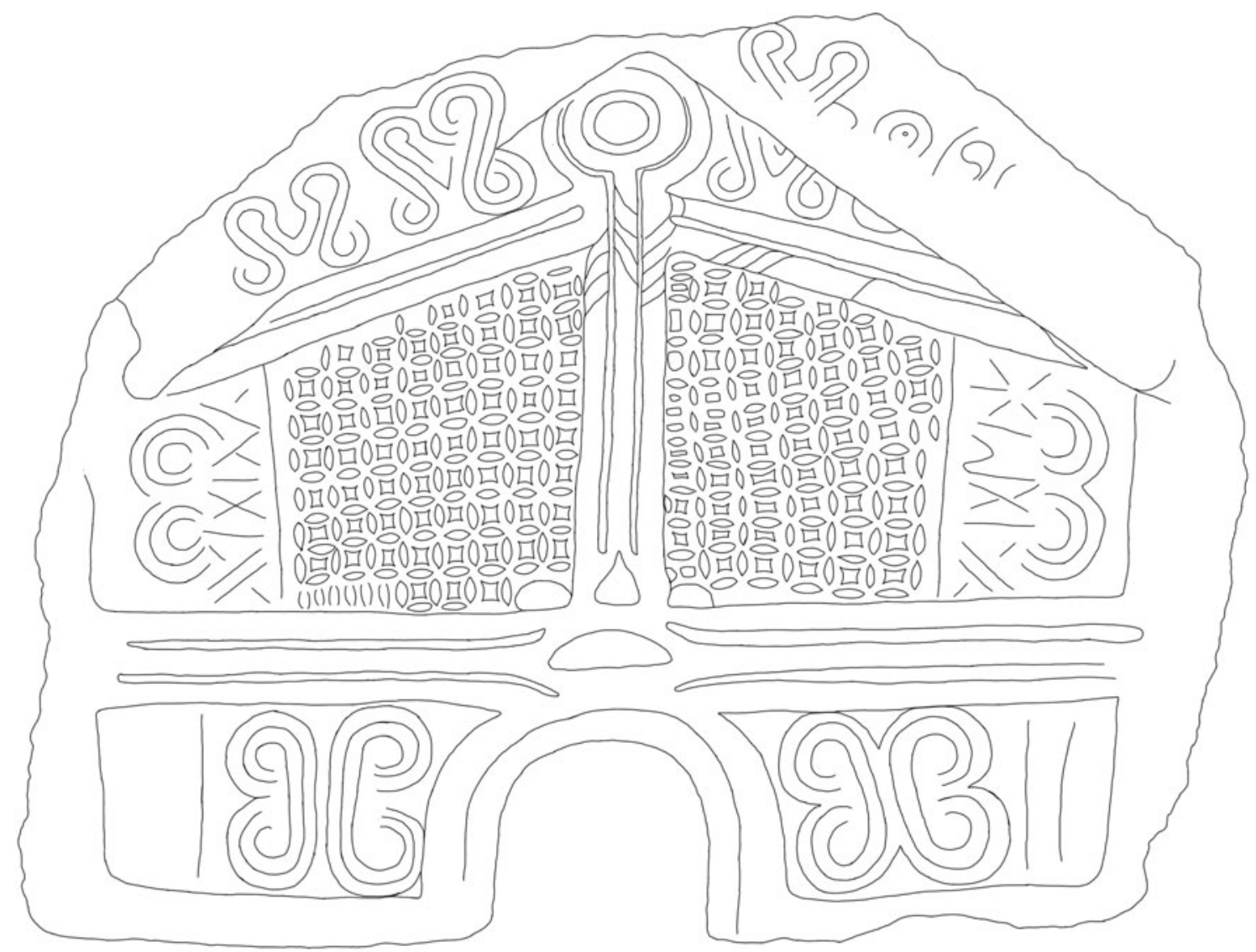

Figure 3. Illustration of pedra formosa \#1 from Briteiros. (Illustration: author.)

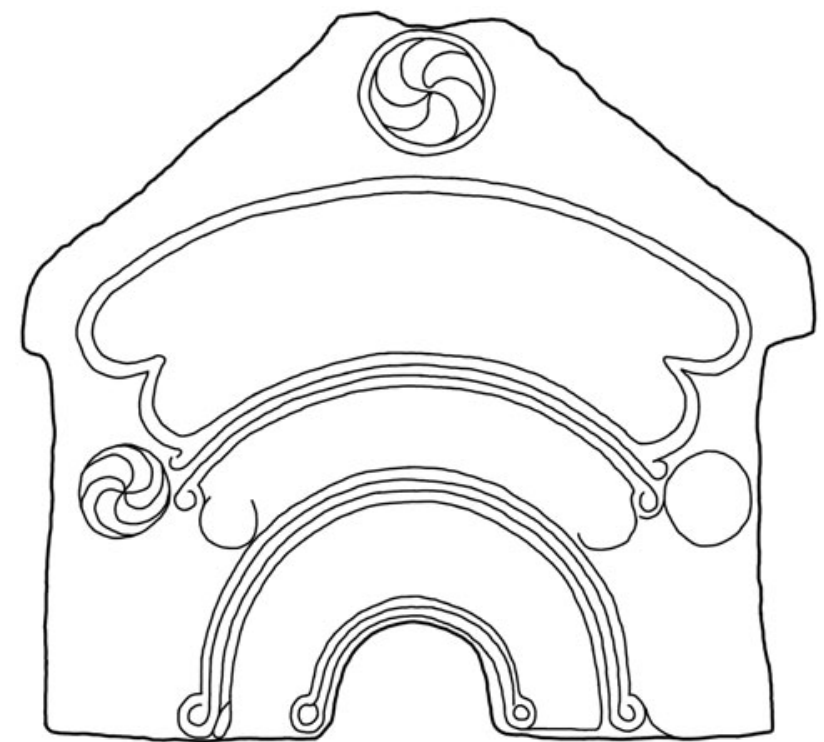

Figure 4. Illustration of pedra formosa \#2 from Briteiros. (Illustration: author.) indigenous invention (Almagro-Gorbea \& ÁlvarezSanchís 1993; Armada Pita 2001; González-Ruibal 2004; Parcero Oubiña \& Cobas Fernández 2004; Silva 2007a), or local copies inspired by Roman bath-houses (Calo Lourido 1993; 1994; Rios González 2000). The idea that these buildings were local attempts to reproduce Roman bath-houses was more credible before the stratigraphic excavation of many of the structures now known; however, since the excavation of the baths at Chao Sanmartín, which have been dated to between the fourth and third centuries BC (Villa Valdés 2002), it has become increasingly clear that the Castro baths pre-date Roman presence in the area. In addition to their earlier appearance, it is evident that the Castro baths served a different function to that of the Roman bath-houses, which were utilized primarily for leisure and social activity (Fagan 2002).

Since the acceptance of the theory that the specialized semi-subterranean structures of the Castro area were used as saunas or baths, it has been assumed that their purpose has been broadly ritual 

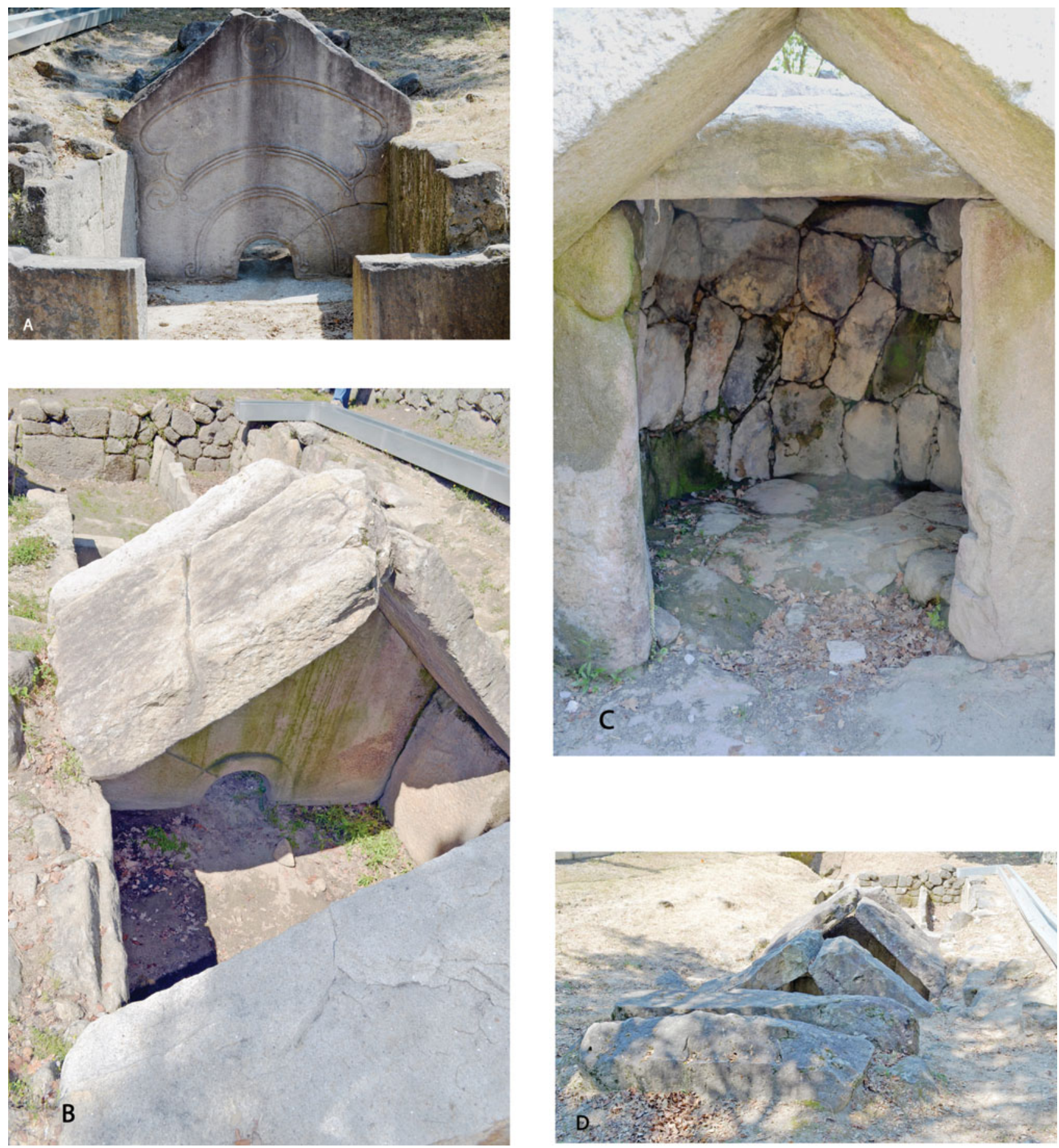

Figure 5. (Colour online) The in situ bath structure at Briteiros. (A) Front view of antechamber and pedra formosa \#2; (B) rear view of pedra formosa \#2 and interior chamber; (C) semi-circular alcove at rear of inner chamber; $(D)$ rear view of entire semi-subterranean bath structure.

(González-Ruibal 2004; Parcero Oubiña \& Cobas Fernández 2004), including the initiation of warriors (Almagro-Gorbea \& Álvarez-Sanchíz 1993; Brañas Abad 2000; González-Ruibal 2004; Lorrio 2005; Silva $2007 \mathrm{a}, \mathrm{b})$, or for ritualized feasting and hospitality (Ar- mada Pita 2001). I do not discount these possibilities, but rather propose an additional explanatory lens for their use that is compatible with these other explanations, based on the layout, position in the landscape and decoration of these ritual structures. 


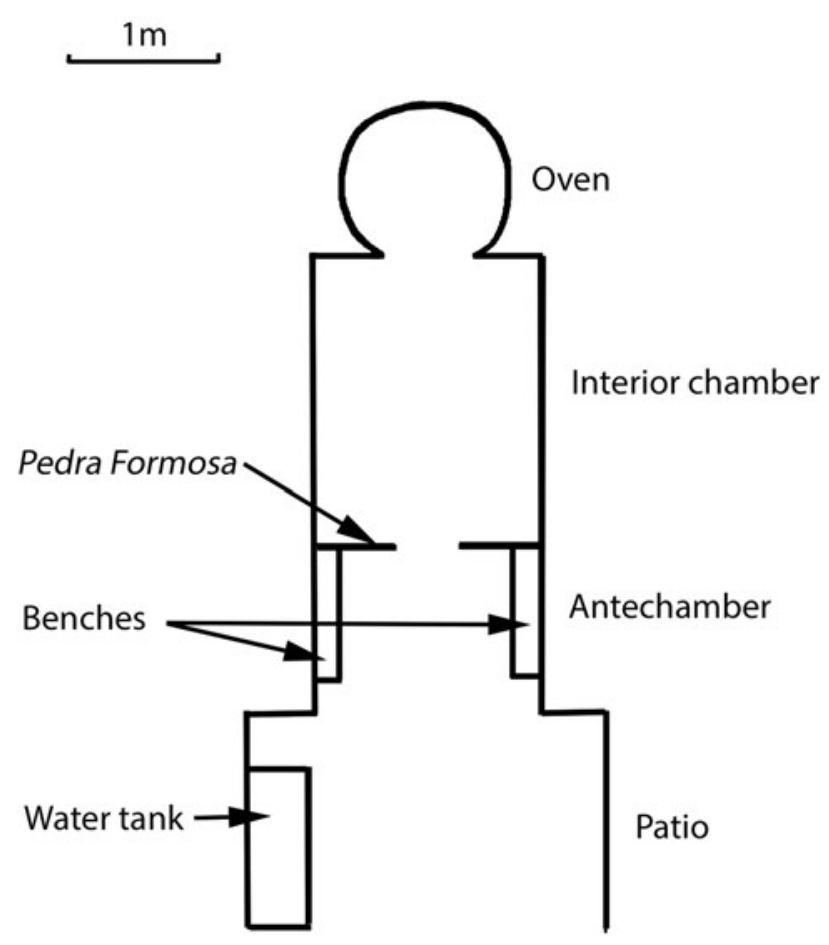

Figure 6. Idealized plan of Douro-Minho baths. (Illustration: author.)

\section{Specialized structure}

The Castro baths have a number of defining characteristics separating them from other structures within Castro settlements, suggesting a specialized function. For instance, their layout and structural typology is unique, working to funnel activity into increasingly restricted areas. The bath structures contained discrete areas used for burning and maintaining fires, they were enclosed, and they also worked to restrict access and movement between spaces. In addition, the structures were semi-subterranean, sunken into the ground or carved from bedrock.

The structure of the baths located in the DouroMinho region follows a unique typology, illustrated in Figure 6. The outer patio or atrium is generally the largest and most open, with areas where water is channelled into small cisterns, followed by a smaller enclosed antechamber, some of which (Braga, Freixo, Sanfins, Alto das Quintãs \& Alto das Eiras) show evidence of benches along the walls (Silva \& Maciel 2004), and is separated from the completely enclosed inner chamber by a large stone slab or the pedra formosa. At the in situ baths at Briteiros and Castro das Eiras (Queiroga \& Dinis 2008/2009, 142), this interior chamber was covered by large granite slabs forming a peaked roof (Fig. 5B), but elsewhere these antechambers may have been covered by timber or thatch. All of these preceding rooms are roughly rectangular, while the innermost alcove, located at the back of the enclosed interior chamber behind the pedra formosa, is smaller, rounded or ovular, and inaccessible except from the interior chamber or by chimney (Fig. 5C). These alcoves display evidence of fire and charring, thus giving these structures the name monumentos com fornos, or 'buildings with ovens', and were likely used to heat water and create steam (García Quintela \& Santos-Estévez 2015; Queiroga \& Dinis 2008/2009; Silva 2007a,b). The semi-circular plan of the oven space offers another contrast to the northern baths, which have a rectangular alcove (Silva 2007a). The baths were built using granite blocks and existing bedrock, and are sunk into the ground, which would have created a low profile for the structure when viewed from the exterior (García Quintela \& Santos-Estévez 2015; Silva 2007a). This, in addition to the enclosed inner chambers and the channelling of water sources into or through the building, may have furthered the impression of a cave-like entrance to the underworld, or connection to chthonic powers.

As noted, alcoves located at the back of the innermost chamber have in some cases (Silva 2007a,b) provided evidence of periods of exposure to fire, which was seemingly limited to these spaces within the structures. For instance, Martins Sarmento (1880) described excavating two burnt stones from this area of the baths at Castro de Eiras, and compared them to similar structures at the sites of Sabroso and Monte de Saia (Queiroga \& Dinis 2008/2009). These fires would have been vented by a small opening or chimney in the false dome covering the alcove, providing perhaps the only evidence from the exterior that the structure was in use (García Quintela \& Santos-Estévez 2015; Silva 2007a).

Phenomenology provides a framework for understanding how the specialized structure of these buildings may have functioned to shape and constrain an individual's physical interaction with their built environment. Advocated by philosopher Maurice Merleau-Ponty as well as archaeologists such as Christopher Tilley and Ruth Van Dyke, phenomenology emphasizes the importance of an individual's embodied interactions with the world. Following Edmund Husserl and Martin Heidegger, Merleau-Ponty believed in a return to 'things themselves' (1965, viii). This entailed a movement away from a mitigated scientific understanding of the world and towards the direct knowledge of the world through an individual's physical perception (Merleau-Ponty 1965, viii). Merleau-Ponty rejected the idea of a consciousness existing outside physical realities, arguing instead that 
every view is a view from somewhere, and that the 'phenomenological world is not pure being, but the sense which is revealed where the paths of my various experiences intersect, and also where my own and other people's intersect and engage each other like gears' $(1965, x x)$. This means that an individual can never grasp the entire reality of a physical object, because the viewer is physically situated in such a way that limits the possibility of other perspectives (Merleau-Ponty 1965,95). It also implies that all perception is relational, and impacted by an individual's experiences with other people. Christopher Tilley (1994) brought this phenomenological view to the practice of archaeology, advocating for a humanist view of landscape and a bodily engagement with it. Like Merleau-Ponty, Tilley $(2008,273)$ believes that the body is the primary tool by which people can investigate their world, and that the limits of the body are the limits of phenomenological practice.

Returning to the Castro structures, a significant aspect of these buildings is their enclosed, restricted nature. For instance, there is some evidence that there may have been doors located at the entrance of these buildings (Queiroga \& Dinis 2008/2009), and movement into and out of the innermost chamber would have been highly circumscribed. The interior chamber was virtually sealed off from the rest of the structure by the granite slab of the pedra formosa, which had only a small opening near the floor allowing ingress and egress. All pedras formosas consistently display a narrow, rounded or semi-circular cut through the central bottom portion of the stone, averaging $50 \mathrm{~cm}$ in width and $42 \mathrm{~cm}$ in height (Calo Lourido 1994). Even allowing for the possibility of a considerably smaller average body size of Castro people, this opening presents limited options for movement from one chamber to the other. Unless the person was a small child, crawling through the opening on hands and knees would not have been feasible. The low clearance afforded by the opening, in addition to its narrowness, suggest that movement would have been restricted to a body moving through lengthwise, with either head or feet preceding. It is possible that a person could have moved through on their stomach, either with arms outstretched ahead, or at the sides; however, the presence of shallow ledges above some openings implies use as hand-grips, and thus that a person would have moved through the opening on their back, with their head or arms first (e.g. Fig. 7).

This way of entering and exiting the interior chamber would have left the person moving between rooms in a vulnerable position, at a disadvantage to protect themselves from potential threats while they transitioned through the small space with portions

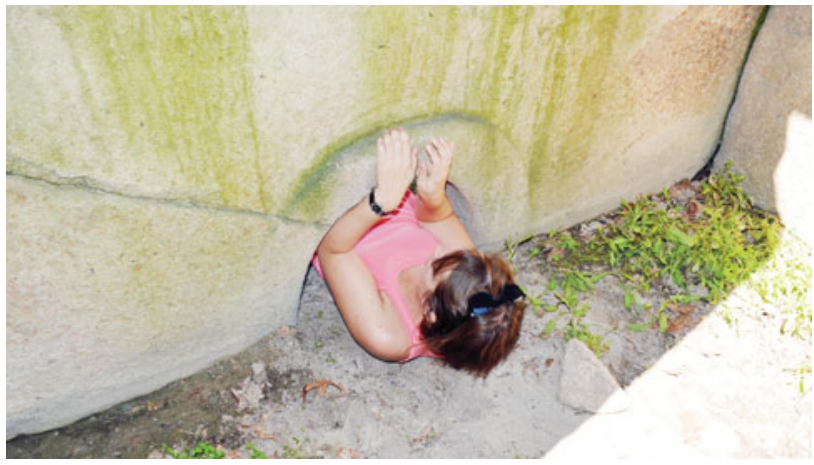

Figure 7. (Colour online) The author navigating the opening of the in situ pedra formosa \#2 at Briteiros, moving from the antechamber to the interior chamber.

of their body on either side of the opening. While it seems unlikely that they would have been in particular danger of harm in such a space, this passage may have represented a symbolic moment of vulnerability and susceptibility to outside forces during a moment of transition. The smallness of the opening also implies that only a limited number of people were allowed access to the interior chamber. The circumscribed structure of these buildings makes it clear that they were not spaces meant for general congregation.

If we view the Castro buildings from a phenomenological perspective that recognizes the primacy of physical perception in an individual's interactions with place, it seems that these structures were built in specific ways in order to invoke particular sensory experiences and to structure bodily movement through space in defined ways. Considering the ways in which these specialized structures were built to constrain movement within their walls, it seems likely that the buildings were meant to evoke particular bodily or sensory experiences, which will be discussed further below.

\section{Placement in landscape}

The Castro baths not only had a specific form related to their function, but their situated presence within the landscape was also significantly linked to their social use. The placement of the baths near to the walls of settlements implies a concern with boundaries and defence, while the location of the baths in the liminal space outside the main settlement nucleus suggests that whatever occurred there could not take place within the heart of the community. Added to these points is the location of each bath along a spring or natural watercourse, gesturing towards the important role of water in the use of these structures. 
The baths appear to be orientated along an east-west axis (Silva \& Maciel 2004), angled slightly northeast-southwest, with the oven alcoves in the northeast and the entrances in the southwest. While it seems likely that these directional alignments relate to the symbolic function of these structures, as argued by García Quintela (2016), their precise significance in relation to the rites performed in them remains unknown.

It is interesting to note that although in most cases the baths were located within the walls of the settlement, they were not included in the heart of the community. In all cases (except possibly Tongobriga), the baths were situated outside the settlement core. For instance, Armada Pita $(2001,80)$ points out that the baths were positioned close to settlement gates or entryways, and suggests that they may have played a role in welcoming guests into the community. García Quintela and Santos-Estévez $(2015,71)$ also point out that though the baths of the northern region are more integrated with the urban layout of sites, they are also positioned near monumental gates, which in my opinion suggests a link between these structures and the idea of passage across thresholds. Sergio Ríos $(2002,379)$ explains the distance of the baths from the settlement core as a function of their structure, suggesting that baths needed to be built down slope in areas of significant sediment accumulation in order to sink them deep enough into the ground to support the heavy stone slabs of the walls and roof. These factors may very well have contributed to the locations chosen for the baths, but I would suggest they were not the only ones, considering the baths at Tongobriga were carved directly out of the bedrock, and therefore the necessity of external support for the walls does not apply. In any case I believe the hypogean nature of the baths can be explained in another way, as I discuss below.

Perhaps the most salient feature of these structures is their connection to water, since without access to water they could not properly be called baths. It is a connection that many scholars have noted (Armada Pita 2001; Calo Lourido 1994; García Quintela \& Santos-Estévez 2015; Parcero Oubiña \& Cobas Fernández 2004; Queiroga \& Dinis 2008/2009; Ríos 2002; Silva 2007a,b). Parcero Oubiña and Cobas Fernández (2004), for instance, believe that the placement of the baths is entirely to do with their ability to access water, and some authors point to the presence of tanks or basins in the patio area as a place for people to submerge themselves in cold water (Armada Pita 2001; Ríos 2002; Silva 2007a,b). Many of the structures also have channels and drainages that helped to manage water flow into the building.
Silva (2007a) reports that large quantities of calcined river pebbles and granite pieces were found in or near the baths at Castro de Galegos, Sanfins, Briteiros and Tongobriga. Silva $(2007 a, 71)$ believes that these stones were heated in the hearth at the back of the structure and then doused in water to produce steam. At Castro de Galegos and Sanfins, outside the structure next to the atrium, there is evidence of accumulated debris including calcined pebbles, charcoal and ash, which could be the result of actions such as cleaning the hearth and the interior of the structure, suggesting repeated use (Almagro-Gorbea \& ÁlvarezSanchís 1993, 189; Silva 2007a, 71). Aside from this debris little else in the way of material culture has been found associated with these structures. This may be the result of their regular cleaning, though it may also be due to many structures having been discovered before the advent of careful stratigraphic recovery of artefacts. It is interesting to note that the water basins are located at one end of these structures, outside the entrances, while the hearth alcoves were placed at the opposite end of the structure, creating a dichotomy of elements. This dichotomy was perhaps further echoed by the alignment of the structures along an east-west axis, as mentioned above, and could have invoked the rising eastern sun and the waters of the western Atlantic.

In relation to the Castro baths, landscape archaeology offers a holistic method of understanding human interaction with our physical surroundings, emphasizing the recursive nature of our relationships with our material environments (Knapp \& Ashmore 1999). A particular focus of landscape archaeology is the important role landscapes play as repositories for social meaning, particularly in relation to identity, memory, and relationships with the divine (Knapp \& Ashmore 1999; Strang 2008; Van Dyke 2008). For instance, Carole Crumley $(1999,272,274)$ points out that in many cultures sacred spaces are modelled after natural elements in the landscape such as mountains, caves and springs, embellished with cultural symbols (a feature of the Castro baths I discuss below) and situated in liminal spaces between the mundane and sacred spheres. Crumley $(1999,274)$ also emphasizes the common phenomenological experience of natural places such as caves, mountains and springs cross-culturally, citing them as possible entry points into other forms of consciousness. I believe the southern Castro baths were geographically situated in ways that evoke these connections with potentially sacred natural spaces.

In contrast to the northern above-ground baths, the southern structures appear to have been constructed to give the impression of being sunken 
or submerged in the surrounding landscape (Silva 2007a); for instance, the structure at Tongobriga was carved directly into the granite bedrock. This emplacement suggests an association with caves or openings in the earth, especially when coupled with the presence of water from nearby springs that collected in cisterns at the entrance to the buildings, and the existence of fire in the depths of the structure. In addition, the granite faces and narrow openings of the pedras formosas are suggestive of natural crevices leading to locations isolated from natural light and outside activity. Ritual practices across much of temperate Europe during the Iron Age took place in locations associated with natural forces, such as in forest groves, by springs, rivers, or oceans, and in caves (Bradley 2000). Similar to bodies of water, in many traditions and mythologies caves occupy a special position as a threshold or access point between worlds with connections to the sacred (Bradley 2017; Brady \& Ashmore 1999; Moyes 2012). It is possible that by creating structures that mimicked the appearance and sensory effect of caves, Castro people were participating in the creation of a sacred landscape that allowed them access to the supernatural.

I believe that the baths of the southern region were carefully placed within the landscape to evoke certain connections with the natural world. Removed from the heart of the settlement, but still within the realm of community control, the baths were artfully created to mirror openings in the earth, natural places which exist on the edges of two different worlds.

\section{Apotropaic symbols}

The most dazzling aspect of the baths was hidden within their structure, shielding the inner chamber from the light, movement and noise of the antechamber and outside world. The pedras formosas of the southern baths are certainly the most striking features of these buildings, and probably the most symbolically significant as well. I argue that the symbols inscribed on the pedras formosas were meant to provide spiritual protection to the occupants of the building, as well as offering a focus and space of affordance (Wells 2012) for whatever took place within the interior chamber and antechamber.

As previously mentioned, the distinguishing feature of the baths in the Douro-Minho region is their decoration, and it is clear that there are certain similarities linking the decorative aspects of these stones, including the marked use of cord designs and wheel motifs. As illustrated in Table 2, six of the stones (Briteiros \#1, Sanfins, Castro de Galegos, Tongobriga,
Castro de Eiras and Alto das Eiras) display some type of cord motif, and three stones, including Briteiros \#2 (see Figures 4, 5A \& 7), Castro de Eiras and Alto das Eiras bear wheel motifs. The presence of these motifs together is significant because there is a noticeable unevenness in the distribution of cord and wheel motifs on the material culture of Castro people. Whereas cord motifs appear on all types of extant material mediums, including ceramics, personal adornment, architecture and sculpture, wheel motifs are limited to items of personal adornment, architecture and sculpture (Prociuk 2016). This dichotomy suggests a difference in meaning or significance between the two motifs, and perhaps indicates that the function of each motif was bound to specific settings or materials. While wheel motifs are limited in their extent, cord motifs appear to be appropriate decoration for all types of objects, suggesting a more universal function.

In conjunction with the use of both cord and wheel motifs on the pedras formosas, there is a consistent pattern on all stones regarding the placement of decoration around the openings. In fact, all eight of the decorated stones from the Douro-Minho region have some type of motif directly associated with the entrance to the interior chamber (González-Ruibal 2004, 131). The stones from four sites (Tongobriga, Sanfins, Alto das Eiras and Briteiros \#1) have cord motifs framing their entrances, while two additional stones have line or torque patterns around the entrance (Castro de Eiras and Briteiros \#2), and finally, the decorated beam at Castro de Galegos rests directly on top of the opening. Additionally, of the two stones that have only a single motif (Sanfins and Tongobriga), both have their decoration framing the entrance. This repeated emphasis on the small openings of the pedras formosas suggests a desire to highlight their presence, implying an importance in the function of these narrow passages.

Alfred Gell (1998) offers a potential explanatory framework for this complex symbolic use, arguing that social relationships can be fostered through art objects, which Gell believes can be any item that mediates social action. A fundamental element of such relationships is to defer returns over time, which establishes 'unfinished business' and extends the social relationship temporally, a process similar to that which occurs when the brain has difficulty grasping complex visual patterns (Gell 1998, 80). Gell discusses the power of decorative patterns to engage the mind in an extended relationship with the decorated object, referring to these complex patterns as 'mind traps' which work to confuse and enthral. This enthralment is what makes apotropaic devices and 
Table 2. Table of symbolic motifs present on individual pedras formosas.

\begin{tabular}{|c|c|c|c|c|c|}
\hline Site & S-pattern & Circles & Crosses & Wheels & Cord \\
\hline Briteiros \#1 & 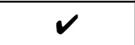 & $v$ & & & 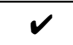 \\
\hline Briteiros \#2 & $\checkmark$ & $\checkmark$ & $\checkmark$ & $\checkmark$ & \\
\hline Sanfins & & & & & $\checkmark$ \\
\hline Santa Maria de Galegos & $\checkmark$ & & & & $\checkmark$ \\
\hline Tongobriga & & & & & $\checkmark$ \\
\hline Castro de Eiras & & $\checkmark$ & & $\checkmark$ & \\
\hline Alto das Eiras & $\checkmark$ & & $\checkmark$ & $\checkmark$ & $\checkmark$ \\
\hline Alto das Quintas & $\nu$ & & & & $V$ \\
\hline
\end{tabular}

patterns effective, because malevolent spirits become distracted in attempting to trace the patterns and are rendered harmless (Gell 1998, 84). As previously discussed, those who participated in the activities that took place within the bath structures would likely have experienced moments of vulnerability as they moved through the narrow passage between the antechamber and the interior chamber. This vulnerability may have been both physical and spiritual, and it is possible that the elaborate designs of the pedras formosas were employed as apotropaic devices to ward off evil influences as people were exposed in moments of transformative passage.

It is also possible that the purpose of the designs was as a meditative device meant to focus the mind and energy of those undergoing rituals performed within these structures. While some of the stones are visually complex, others have large blank spaces without visible decoration. In his discussion of the distinct modes of visualization in the Iron Age, Peter Wells (2012) draws on James Gibson's (1977) theory of affordances to help understand the visual and psychological purpose of the blank areas left on some Bronze and Iron Age objects. This purpose, according to Wells $(2012,32)$, is to allow the mind the possibility of action', to afford the viewer the ability to pursue their own ideas of what should appropriately fill that space. It is possible, therefore, that the un-carved spaces on the pedras formosas afforded their viewers unrestrained potentialities of imagination, and allowed the mind to venture into deeper waters than usually navigated.

An alternative to this hypothesis may be that the un-carved spaces on the pedras formosas were in fact covered with other types of decoration that have not been preserved, such as painted designs, or textiles; for instance, there is some evidence from Castro de Eiras that the interior of the antechamber was covered in a layer of clay (Queiroga \& Dinis 2008/2009, 142$3)$, which would have provided a receptive surface to painted, incised or stamped decoration.
A number of authors (Almagro-Gorbea \& Alvarez-Sanchís 1993; Brañas Abad 2000; García Quintela 2016; Ríos 2002; Silva 2007a) have characterized the symbolic motifs on the pedras formosas as astral in nature, generally without reference to specific motif types. I assume they are primarily referring to the wheel or triskele motifs present on three of the pedras formosas (see Table 2), which have been interpreted as representing the rays of the sun or motion of the stars (Green 1984). Given the apparent directional alignments of these structures and their emplacement in relation to settlement cores, as discussed above, a connection with astral imagery and celestial movement seems plausible. Brañas Abad (2000, 104-6) in particular links the presence of astral motifs to the interpretation of the baths as representing a place of passage to the afterlife, or the Beyond. However since we do not know the precise meanings these symbols held for the Castro people, we should be cautious in assigning too specific an interpretation to this rather nebulous concept.

The symbolic motifs that give pedras formosas their name represent a unique element of the southern baths, and suggest a link to a wider ideological world-view inaccessible to modern viewers. Whether that purpose was to ward against negative powers, facilitate an altered state of consciousness, or to invoke supernatural beings and passage to other worlds, we may never know. Whatever their original meanings, it seems clear that the motifs framing the entries into the interior chambers served not only a decorative purpose, but a symbolically meaningful one as well.

\section{Discussion}

The Iron Age world inhabited by the Castro people was fraught with unstable political structures and challenging social connections. Though not immediately threatened by the conflict between the Carthaginians and Romans, the people of the Castro Culture nevertheless were faced with the 
knowledge that their territories, livelihood and ways of life could at any time be endangered by the military powers engaged on their doorstep, as eventually came to pass with the Roman encroachment across the Iberian Peninsula. Of necessity the communities of the Iron Age developed different ways of coping with these potential threats, whether by increasing isolation, forming alliances, defensive posturing, or formulating spiritual protections for their people and settlements. It is this later mechanism, I believe, which the Castro people employed to guard against the perceived external threats posed by their turbulent social sphere. Since they could not cut themselves off from the outside world, which they relied on for trade and political alliances, Castro communities turned to the use of specialized structures to cleanse and purify those who left the safety of the community to venture into the wider world.

In Ulysses' Sail, Mary Helms (1988) provides a useful framework for understanding how the Castro people may have envisioned their world and the dangers associated with it. Helms discusses the ways in which distance can be conceptualized by different societies, including the notion that distance relates not only to space, but also to time. For Helms, at the heart of the concept of distance lies the fact of separation, which distinguishes between that which is near and familiar, against that which is 'not near' and therefore strange and potentially threatening (Helms 1988, 9). Distance may also represent a spiritual separation between the sacred and profane, where the known, ordered world of everyday life within the community gives way to the potential for mystery and sacred power outside the bounds of social life. The farther the distance, whether spatial or temporal, the greater the potential for difference and contamination, but also for sacredness. Those who venture beyond the safety of the community risk exposing themselves to impurity and the danger of the unfamiliar, but also open themselves to new forms of knowledge and power, which, according to Helms, they may use to their advantage when they re-enter their communities. These distant travellers may become religious figures engaging with the mysteries of the sacred, political leaders who have gained knowledge of foreign affairs and ways of life, or traders and craftspeople that bring strange new goods and technologies back to their homes and make them palatable for domestic consumption. However, this new knowledge and status comes at the cost of potential contamination that must be guarded against, especially upon re-entry into the community. Kristian Kristiansen and Thomas Larsson pick up this thread in their discussion of Bronze Age Society, and write:
Space is neither homogeneous nor neutral, except on archaeological distribution maps. It is loaded with dangers, monsters, myths and powers, it is qualitatively differentiated, and to enter it or return from it demands complex measures. (Kristiansen \& Larssen 2005, 43)

Long distance travellers were exposed to danger and contagion, and specialized procedures would have been required in order for them to neutralize such threats and return to a state of harmony within their communities. The Castro bath structures may have served in this capacity, functioning as ritual spaces designed for purification and rites of transition. The evidence for this lies in their specialized structure, their placement in relation to communities and their decoration.

The structure of the Castro baths suggests that they played a specific role in the life of community members. As both Silva (2007a) and García Quintela (2016) point out, the bath structures are uniquely monumental in their construction in comparison to the rest of the Castro built environment. Unlike other Castro structures, which are largely composed of smaller granite blocks, the baths are built of megalithic slabs of granite, which would have involved a considerable outlay of resources to quarry, transport and assemble, or, in the case of Tongobriga, hew directly from the bedrock. Also unlike other buildings within Castro settlements that do not appear to follow coherent formal plans, the baths are clearly recognizable by their unique structural typology as being distinct from the domestic units of the community. By far the most common type of structure present in Castro sites, the typical domestic unit often appears to be idiosyncratically laid out, and does not conform to a standardized typology. In contrast, the bath structures are all nearly identical in their layout, suggesting that there was a shared template of what such structures should look like, and by extension a similarly common understanding of their use. This use is hinted at in the restricted access of the interior chamber, cut off from the more accessible outer areas by the often elaborately decorated pedras formosas with their tiny openings. The alcoves providing space for fire at the back of these interior chambers also gesture towards the specific function of these spaces for heating stones or water and creating steam in the isolated interior, or for burning herbs or other materials, as suggested by Almagro-Gorbea and Álvarez-Sanchís (1993).

These structures provided restricted spaces that were cut off from the everyday world. With limited natural light, the baths encased their occupants in a dark world of stone, offering shelter and secrecy for the events taking place within them. The benches 
lining the walls of the outer chamber suggest that one or more people were stationary there for a period of time, but the narrow opening of the pedra formosa allowed only a single person entry at a time, making it likely that the interior chamber held fewer people. Perhaps the successive chambers of the bath structures, from patio to outer chamber to inner chamber, represented the stages of a journey, from the exterior world of light and everyday life to a dark interior world characterized by the elements of fire and water, surrounded by stone and anchored in the earth, and then returning outward again.

In addition to their location near to natural water sources, the placement of the Castro baths indicates that they were considered marginal spaces in relation to the community. As Chris Fowler notes:

Liminal places of ritualized personal transformations are located in liminal places and times. These transformations include not only mortuary practices but other rites of passage such as initiation into adulthood and acts intended to heal, purify, fulfill a debt or relationship, or bring on personal revelation. (Fowler 2008, 293)

The Castro baths were situated near to the outer walls of the settlement, close to gates or access points, but away from the core of the community. I would suggest that the baths were located on the peripheries of settlements because they could not safely be included within them. If the purpose of a bath is to remove impurities, locating structures for this use outside of the community core would help to avoid contamination. Just as a gate is a transitional space or threshold that touches both the interior and exterior, the baths may have been a space in which to move from one place to another in terms of spiritual transition. Moments of transition are often fraught with both potential and uncertainty, and it is possible that the power and potential danger of the transitional rituals taking place within the saunas needed to be contained within a safe space away from the heart of the community.

Likewise the placement of these structures close to water sources strongly contributes to the hypothesis that they were places of cleansing. Aside from the obvious continued usage of water for numerous types of cleansing purposes, steam is used even today as a powerful cleanser and disinfectant. Veronica Strang (2008) discusses the importance of the imaginative aspects of water, citing its close connections to ideas about physical, spiritual, and moral wellbeing. Another significant aspect of water Strang $(2008,125)$ notes is the physiological affects of water on human bodies, integral not only to our continued survival but also in stimulating or soothing our nervous systems.
In particular Strang $(2008,125)$ mentions the 'mesmeric effects' of gazing on water, which may be reflected in the symbols carved on the pedras formosas of the Castro baths. Therefore, coupled with the presence of apotropaic symbols present in these structures, their purificatory function seems highly probable.

It is clear that the symbolic motifs of the pedras formosas played a greater role in the function of the bath structures than mere decoration. The symbols used on the pedras formosas were the same as those found on other aspects of Castro material culture, though they appear on different types of objects. Wheel motifs are found primarily on items of adornment and architecture, while cord motifs span the gamut of Castro materials, suggesting circumscribed applicability for wheel motifs. Their link to other architectural contexts such as domestic spaces, as well as their use in personal adornment, suggests that wheel motifs may have been used apotropaically to shield the people and spaces on which they appeared. The intricate pattern of some of the pedra formosa designs may also have worked to focus the mind of the viewer into specific pathways of thought and feeling appropriate to the activities taking place within the structure. The areas not occupied by symbols may have served just as important a function, offering a space of affordance upon which a viewer could project any number of possibilities. In addition, the composition of the building itself should not be overlooked. The colour, rough texture and hardness of the granite may have played a role in the perceived properties of the pedras formosas, while the light reflected from the quartz inclusions in the granite may have been particularly striking when viewed by lamplight in the darkened interior of the antechamber.

A final interesting issue to consider is the question of whether each Castro settlement had a bath structure, or if only certain settlements required the regular use of one. The issue of site hierarchy amongst Castro settlements is thorny and still needs to be adequately addressed, but while Briteiros and Sanfins are two of the largest and arguably most significant Castro settlements, other large sites such as Monte Mozinho, Terroso and Bagunte do not currently have known baths associated with them. In addition, seemingly smaller, less significant sites such as Santa Maria de Galegos or Alto das Quintas do have baths, leading to the question of why some sites went to the likely considerable expense of creating these monumental structures, while others did not. Were some settlements closer to natural sites that functioned in the same way the built structures did? Were some settlements more in contact with outside groups and therefore more at risk of contamination? Was the building 
of a bath an aspirational move intended to increase the social, political, or religious consequence of a settlement? Further careful excavation at many of the already known castros may help answer these questions.

Castro people were witness to periods of relative stability in the Early Iron Age, followed by rapid transformation both of their material culture and the social and political shape of the world around them. With the approach of and eventual occupation by Roman forces, the Castro people were forced to contend with the uncertainty of their continued lifeways, and it appears that in part their response to this involved the proliferation of certain indigenous traits alongside the adoption of Roman imports and likely customs as well. This can be seen in the continued use of the baths even during the period of Roman expansion into the area, most clearly illustrated at the site of Tongobriga, where Roman thermae and Castro baths existed literally side-by-side (García Quintela \& Santos-Estévez 2015), clearly serving different needs in a newly heterogeneous community. This proliferation can also be seen in elements of architectural decoration found at different castros, where complex patterns were laboriously carved into granite beams and plaques. Matching patterns can be seen stamped on later period ceramics, and wrought in gold and silver on items of personal adornment, such as torques. These motifs are undeniably local in character, in use since the end of the Bronze Age, but they reach a peak of proliferation across material culture at the end of the Castro period, when the threat of Roman occupation had become a reality. The fluorescence of these decorative styles represents, perhaps, a way of asserting local identity and history in the face of inexorable cultural change. The construction and use of the baths, at their most ornate, appears also to have been at the end of the Castro period (Parcero Oubiña \& Cobas Fernández 2004) and may similarly have functioned to root the Castro people in their traditions, despite the transformations their society was undergoing. As with any cultural change, it is possible that some members of Castro communities may have embraced the new regime and the opportunities it afforded, while others turned to more traditional aspects of their culture as a form of resistance, or that individuals chose selectively which new customs to adopt and which to maintain from their past.

\section{Conclusions}

The Castro people, in their social spheres and their physical environments, were faced with the instability of boundaries. As with all social groups, Castro communities were forced to define what constituted 'us' versus 'other'. Their settlement structures demonstrate this act of definition, through the evidence of major defensive structures such as earthworks and masonry walls, but also in the isolation of each domestic unit from the others, with clustered compounds surrounded by stone walls. Within their communities, Castro people created spaces of belonging, surrounding themselves with barriers which focused gaze and activity inward, to the heart of the domestic unit. With their walls Castro people drew the limits of inclusion, thereby defining not only what belonged on the inside, but also the boundaries of the exterior and everything that was 'not us' or 'not ours'. Helms addresses the nature of such boundaries when she writes:

Boundaries keep all eyes turned back, inward toward the center, or, for those who must venture forth, mark the point where ritual protection must begin to safeguard travelers and where purification must take place on their return before they may safely re-enter society. (Helms 1988, 28)

In light of this need to protect and purify at the point of boundary crossings, it is significant that the Castro bath structures were placed on the margins of their communities, close to walls and entry points. This placement highlights the fragility of the border, the inherent danger of exposing the interior to the vagaries of the outside world. And yet what could they do but risk such exposition? The Castro people could not survive without external connections, without trade and the exchange of knowledge and ideas and without relationships with those who also inhabited their world. The external threats facing the people of the Castro Culture were real, but so were the opportunities they encountered venturing far from their home shores. I argue that, to reconcile these conflicting realities, the Castro people, like all those living through turbulent times, devised ways of coping with the potential dangers of their world. They did this by formulating rituals of purification that eased the tension of boundary crossing, working to ensure the continued safety of the community from the threats posed by those who had ventured into unknown territories. Though they could not control the chaotic forces at work in their world, Castro people could guard themselves against the perceived threat of contamination from the unknown, thereby also enabling themselves to take advantage of the flow of relationships, knowledge and goods provided by connections to their wider world.

Nadya H. Prociuk

Texas Archeological Research Laboratory University of Texas at Austin 116 Inner Campus Dr. G6000 
Austin, TX 78712

USA

Email:nprociuk@utexas.edu

\section{References}

Almagro-Gorbea, M. and Álvarez-Sanchís, J.R., 1993. La 'sauna' de Ulaca: saunas y baños iniciáticos en el mundo céltico. Cuadernos de Arqueología de la Universidad de Navarra 1, 177-253.

Almeida, C.A.F., 1974. O monumento con forno de Sanfins e as escavacoes de 1973, in Actas do III Congreso $\mathrm{Na}$ cional de Arqueología. Porto: Ministério da Educação Nacional, 149-72.

Armada Pita, X.-L., 2001. Monumentos termais castrexos: unha contribució á súa interpretación. Annuario Brigantino $24,61-82$.

Azevedo, A., 1946. O monumento funerario da Citania. Revista de Guimaráes 56(1-2), 150-64.

Bradley, R., 2000. An Archaeology of Natural Places. London: Routledge.

Bradley, R., 2017. A Geography of Offerings: Deposits of valuables in the landscapes of ancient Europe. Oxford: Oxbow.

Brady, J.L. \& W. Ashmore, 1999. Mountains, caves, water: ideational landscapes of the ancient Maya, in Archaeologies of Landscape: Contemporary perspectives, eds. W. Ashmore \& A.B. Knapp. Malden (MA): Blackwell, 124-45.

Brañas Abad, R., 2000. Deuses, heroes e lugares sagrados na cultura castrexa. Santiago: Sotelo Blanco.

Calo Lourido, F., 1993. A Cultura Castrexa. Vigo: A Nosa Terra.

Calo Lourido, F., 1994. A Plástica da Cultura Castrexa GalegoPortuguesa. La Coruña: Fundación Pedro Barrié de la Maza, Conde de Fenosa.

Chamoso Lamas, M., 1955. Santa Marina de Aguas Santas (Orense), Cuadernos de Estudios Gallegos 10(30), 41-88.

Conde Valvís, F., 1955. Las termas romanas de la 'Cibdá' de Armea en Santa María de Aguas Santas, in III Congreso Nacional de Arqueología, Galicia 1953. Zaragoza: Institución 'Fernando el Católico', 432-46.

Crumley, C.L., 1999. Sacred landscapes: constructed and conceptualized, in Archaeologies of Landscape: Contemporary Perspectives, eds. W. Ashmore \& A.B. Knapp. Malden (MA): Blackwell, 269-76.

Diodorus Siculus, 1961. Diodorus of Sicily (trans. C.H. Oldfather). (Loeb Classical Library.) Cambridge (MA): Harvard University Press.

Fagan, G.G., 2002. Bathing in Public in the Roman World. Ann Arbor (MI): University of Michigan Press.

Fernández Fuster, L., 1953. Sobre la interpretación de los monumentos con 'pedras formosas'. Archivo Español de Arqueología 26, 379-84.

Fowler, C., 2008. Landscape and personhood, in Handbook of Landscape Archaeology, eds. B. David \& J. Thomas. Walnut Creek (CA): Left Coast Press, 291-9.
García Quintela, M., 2016. Sobre las saunas de la Edad del Hierro en la Península ibérica: novedades, tipologías e interpretaciones. Complutum 27(1), 109-30.

García Quintela, M. \& M. Santos-Estévez, 2015. Iron Age saunas of northern Portugal: state of the art and research perspectives. Oxford Journal of Archaeology 34(1), 67-95.

Gell, A., 1998. Art and Agency: An anthropological theory. Oxford: Clarendon Press.

Gibson, J.J., 1977. The theory of affordances, in Perceiving, Acting, and Knowing: Toward an ecological psychology, eds. R. Shaw \& J. Bransford. Hillsdale (MI): Lawrence Erlbaum, 67-82.

Gomez Tabanera, J.M., 1980. Aspectos de la cultura castreña en sus manifestaciones en Asturias y de los modos de producción en las sociedades protohistóricas del NW. de la Península Ibérica, in Actas do Seminario de Arqueologia do Noroeste Peninsular 2. Guimaráes: Sociedade Martins Sarmento, 87-110.

González-Ruibal, A., 2004. Artistic expression and material culture in Celtic Gallaecia. e-Keltoi: Journal of Interdisciplinary Celtic Studies 6, 113-66.

Green, M., 1984. The Wheel as a Cult-Symbol in the RomanoCeltic World, With Special Reference to Gaul and Britain. Brussels: Latomus.

Helms, M.W., 1988. Ulysses' Sail: An ethnographic Odyssey of power, knowledge, and geographical distance. Princeton (NJ): Princeton University Press.

Knapp, A.B. \& W. Ashmore, 1999. Archaeological landscapes: constructed, conceptualized, ideational, in Archaeologies of Landscape: Contemporary perspectives, eds. W. Ashmore \& A.B. Knapp. Malden (MA): Blackwell, 1-30.

Kristiansen, K. \& T. Larsson, 2005. The Rise of Bronze Age Society: Travels, transmissions and transformations. Cambridge: Cambridge University Press.

Lemos, F.S., G. Cruz, J. Fonte \& J. Valdez, 2011. Landscape in the late Iron Age of northwest Portugal, in Atlantic Europe in the First Millennium BC: Crossing the divide, eds. T. Moore \& X.-L. Armada. Oxford: Oxford University Press, 187-204.

Lorrio, A.J. \& G.R. Zapatero, 2005. The Celts in Iberia: an overview. e-Keltoi: Journal of Interdisciplinary Celtic Studies 6, 167-254.

López Cuevillas, F.A., 1933. A área xeografica da cultura norte dos castros, in Homenagem a Martins Sarmento. Guimarães: Sociedade Martins Sarmento, 99107.

Merleau-Ponty, M., 1965. Phenomenology of Perception (trans. C. Smith). London: Routledge \& Kegan Paul.

Monteagudo, L., 1952. Monumentos propiedad de la Sociedad Martins Sarmento. Archivo Español de Arqueología 25, 112-16.

Moyes, H., 2012. Sacred Darkness: A global perspective on the ritual use of caves. Boulder (CO): University Press of Colorado.

Parcero Oubiña, C. \& I. Cobas Fernández, 2004. Iron Age archaeology of the northwest Iberian peninsula.e-Keltoi: Journal of Interdisciplinary Celtic Studies 6, 1-72 . 
Pena Graña, A., 1999. Notas sobre la organización institucional celta en los territories políticos autónomos (Trebas) de la antigua Gallaecia, in Os Celtas da Europa Atlántica. Actas do $I^{\circ}$ congreso galego sobre a cultura celta, Ferrol, agosto 1997. Ferrol: Concello de Ferrol, 11160.

Prociuk, N.H., 2016. Inscribing Identity: A Case Study of Symbolic Communication from the Iron Age Castro Culture of North-western Iberia. PhD dissertation, University of Texas at Austin.

Queiroga, F., 2003. War and Castros: New approaches to the northwestern Portuguese Iron Age. (BAR International series S1198.) Oxford: British Archaeological Reports.

Queiroga, F.R. \& A.P. Dinis, 2008/2009. O Balneário castrejo do Castro das Eiras. Portugalia (n.s.) 29-30, 143-52.

Ríos González, S., 2000. Consideraciones funcionales y tipológicas en torno a los baños castreños del Noroeste la Península Ibérica. Gallaecia 19, 93-124.

Ríos, S., 2002. Edificios balnearios en castros del noreste de la Península Ibérica. Precisiones en torno a sus características estrucurales y cronología. Bolskan 19, 377-92.

Romero Masiá, A., 1976. El habitat castreño. Santiago de Compostela: Colegio de Arquitectos de Galicia.

Sarmento, F.M., 1880. Observações acerca do Vale de Âncora. O Pantheon 1, 63-7.

Sastre, I., 2011. Social inequality during the Iron Age: interpretation models, in Atlantic Europe in the First Millennium BC: Crossing the divide, eds. T. Moore \& X.-L. Armada. Oxford: Oxford University Press, 264-84.

Silva, A.C.F., 1983/1984. A Cultura Castreja no Noroeste de Portugal: habitat e cronologias. Portugalia 4/5, 121-9.

Silva, A.C.F., 2007a. A Cultura Castreja no Noroeste de Portugal (2nd edn). Paços de Ferreira: Câmara Municipal de Paços de Ferreira, Museu Arqueológico da Citânia de Sanfins/Centro de Arqueologia Castreja e Estudos Célticos.
Silva, A.C.F. (ed.), 2007b. Pedra Formosa: Arqueologia experimental - Vila Nova de Famalição. Lisbon: Câmara Municipal de Vila Nova de Famalicão, Museu Nacional de Arqueologia.

Silva, A.C.F. \& T.D.P. Maciel, 2004. Balneários castrejos do Noroeste peninsular. Notícia de um novo monumento do Castro de Roques. Portugalia (n.s.) 25, 115-31.

Strabo, 1903. The Geography of Strabo. Literally translated, with notes (trans. H.C. Hamilton). (Bohn's Classical Library Vol 1.) London: George Bell \& Sons.

Strang, V., 2008. The social construction of water, in Handbook of Landscape Archaeology, eds David, \& J. Thomas. Walnut Creek (CA): Left Coast Press, 123-30.

Tilley, C., 1994. A Phenomenology of Landscape: places, paths, and monuments. Oxford: Berg.

Tilley, C., 2008. Phenomenological approaches to landscape archaeology, in Handbook of Landscape Archaeology, eds. B. David \& J. Thomas. Walnut Creek (CA): Left Coast Press, 271-6.

Van Dyke, R., 2008. Memory, place, and the memorialization of landscape, in Handbook of Landscape Archaeology, eds David \& J. Thomas. Walnut Creek (CA): Left Coast Press, 277-84.

Villa Valdés, Á., 2002. Sobre la secuencia cronoestratigráfica de los castros asturianos (siglos VIII a.C.-II d.C.). Trabajos de Prehistoria 59(2), 149-62.

Wells, P., 2012. How Ancient Europeans Saw the World: Vision, patterns, and the shaping of the mind in prehistoric times. Princeton (NJ): Princeton University Press.

\section{Author biography}

Nadya H. Prociuk is an Associated Researcher at the Texas Archeological Research Laboratory at the University of Texas at Austin. Her work focuses on issues of identity, symbolic communication, and interregional trade and exchange in the European Bronze and Iron Ages, as well as in Mesoamerica and the American Southeast. 